\title{
PENGARUH SINBIOTIK KEFIR TEPUNG PISANG BATU (Musa balbisiana) TERHADAP KADAR GLUKOSA DARAH TIKUS SINDROM METABOLIK
}

\section{The Effects of Synbiotic Kefir Banana (Musa balbisiana) Flour on Blood Glucose Level of Metabolic Syndrome Rats}

\author{
Dhea Marliana Salsabila*, Taufik Maryusman, lin Fatmawati \\ Program Studi IImu Gizi, Fakultas IImu Kesehatan, Universitas Pembangunan Nasional "Veteran" Jakarta \\ Jl. RS Fatmawati, Pondok Labu, Jakarta Selatan 12450 \\ *Email: dmsalsabila@gmail.com
}

\begin{abstract}
Metabolic syndrome begins with insulin resistance characterized by hyperglycemia. Synbiotic kefir banana (Musa balbisiana Colla) flour reduces blood glucose level. This study was conducted to analyze the effects of synbiotic kefir banana (M. balbisiana) flour on blood glucose level of metabolic syndrome rats. This study used 24 Sprague Dawley.rats which were divided into four groups, i.e. negative control was given standard diet, positive control was given high fat fructose diet (HFFD), treatment I (PI) and treatment II (PII) were given HFFD and synbiotic kefir banana (M. balbisiana) flour 1.8 $\mathrm{mL} 200 \mathrm{~g}^{-1}$ rat $B W$ per day (PI) and $3.6 \mathrm{~mL} 200 \mathrm{~g}^{-1}$ rat $B W$ per day (PII), respectively, for three weeks. The result showed a significant difference $(p=0.000)$ in blood glucose after giving synbiotic kefir banana (M. balbisiana) flour. Synbiotic kefir banana (M. balbisiana) flour reduced blood glucose level in metabolic syndrome rats.
\end{abstract}

Keywords: banana flour, blood glucose level, kefir, metabolic syndrome, synbiotic

\begin{abstract}
ABSTRAK
Sindrom metabolik diawali resistensi insulin yang ditandai hiperglikemia. Sinbiotik kefir tepung pisang batu (M. balbisiana) menurunkan kadar glukosa darah. Penelitian ini dilakukan untuk menganalisis pengaruh sinbiotik kefir tepung pisang batu ( $M$. balbisiana) terhadap kadar glukosa darah tikus sindrom metabolik. Penelitian ini menggunakan 24 tikus Sprague Dawley yang dibagi menjadi empat kelompok, yaitu kontrol negatif yang diberi pakan standar, kontrol positif yang diberi high fat fructose diet (HFFD), dan perlakuan I (PI) serta perlakuan II (PII) yang masing-masing diberi HFFD dan sinbiotik kefir tepung pisang batu (M. balbisiana) 1,8 mL $200 \mathrm{~g}^{-1}$ BB tikus per hari (PI) dan 3,6 mL $200 \mathrm{~g}^{-1}$ BB tikus per hari (PII) selama tiga minggu. Hasil menunjukkan perbedaan kadar glukosa darah setelah pemberian sinbiotik kefir tepung pisang batu ( $M$. balbisiana) secara signifikan ( $p=0,000)$. Sinbiotik kefir tepung pisang batu ( $M$. balbisiana) menurunkan kadar glukosa darah tikus sindrom metabolik.
\end{abstract}

Kata Kunci: kadar glukosa darah, kefir, sinbiotik, sindrom metabolik, tepung pisang batu 


\section{PENDAHULUAN}

Sindrom metabolik menurut International Diabetes Federation (IDF) diderita oleh $20-25 \%$ yang diantaranya pria sebesar $8-24,2 \%$ dan wanita sebesar 746,5\% (Rahmawati et al. 2017). Prevalensi sindrom metabolik meningkat seiring penambahan usia (Fernandes dan Lofgren 2011), yaitu $10 \%$ pada kelompok usia 20 tahun dan $40 \%$ pada kelompok usia 60 tahun (Damiri et al. 2018). Indonesia memiliki prevalensi sindrom metabolik sebesar $23 \%$ (Suhaema dan Masthalina 2015). Sindrom metabolik terjadi saat kondisi progresif berupa kelainan metabolik yaitu obesitas, resistensi insulin, hiperglikemia, dislipidemia, dan hipertensi (Srikanthan et al. 2016). Sindrom metabolik memiliki lebih dari atau sama dengan tiga dari lima kelainan metabolik (Gill et al. 2017).

Sindrom metabolik diawali dengan obesitas dan resistensi insulin (Govers 2015). Saat obesitas, terjadi peningkatan asam lemak bebas yang meningkatkan glukoneogenesis dan resistensi insulin (Rahmawati et al. 2017). Resistensi insulin membuat glukosa tidak dapat diserap sel dan tetap berada dalam darah yang memicu produksi insulin berlebih (hiperinsulinemia) (Yin et al. 2013). Produksi insulin yang meningkat akan melemahkan sel $\beta$ pankreas yang memicu terjadinya peningkatan kadar glukosa darah (hiperglikemia) (Gandhi 2017). Tatalaksana nonfarmakologis membantu menurunkan kadar glukosa darah dan komplikasi sindrom metabolik dengan memanfaatkan pangan fungsional seperti prebiotik dan probiotik

Probiotik merupakan mikroorganisme epitel usus yang memberikan manfaat kesehatan (Rashid dan Sultana 2016). Produk probiotik salah satunya adalah kefir (Nurliyani et al. 2015). Kefir susu kambing merupakan produk fermentasi dengan penambahan bakteri dan khamir (Martharini dan Indratiningsih 2017). Khamir berkontribusi dalam menyediakan faktor pertumbuhan bakteri (Li et al. 2011). Bakteri berperan dalam memelihara mikroflora usus untuk memperbaiki sensitivitas insulin sehingga kadar glukosa darah dapat terkontrol (Ruan et al. 2015). Penelitian pada tikus yang diinduksi aloksan menunjukkan penurunan kadar glukosa darah dari 190,69 \pm
$13,8 \mathrm{mg} \mathrm{dL}^{-1}$ pada hari ke-20 menjadi 182,84 $\pm 15,02 \mathrm{mg} \mathrm{dL}^{-1}$ pada hari ke-40 setelah pemberian probiotik $3,6 \mathrm{~mL} 200 \mathrm{~g}^{-1}$ berat badan (BB) tikus per hari (Al-Shemmari et al. 2018). Pertumbuhan probiotik dipengaruhi prebiotik yang menyediakan substrat spesifik proses fermentasi (Moroti et al. 2012).

Prebiotik sebagai serat pangan terfermentasi memberikan perubahan aktivitas mikroflora usus (Wahyuni dan Syauqy 2015). Pisang memiliki kandungan prebiotik yang mudah ditemui di Indonesia (Muhidin et al. 2019). Pisang batu ( $M$. balbisiana) sebagai jenis pisang plantain lebih baik untuk dijadikan tepung (MartínezCastaño et al. 2019). Pisang batu ( $M$. balbisiana) memiliki kandungan prebiotik Fruktooligosakarida (FOS) sebanyak 427,03 $\mathrm{mg} \mathrm{mL}^{-1}$, pati resisten sebesar $39,35 \%$ (Musita 2012), dan inulin sebanyak $1{\mathrm{~g} 100 \mathrm{~g}^{-1}}^{-1}$ berat pisang (Wahyuni dan Syauqy 2015). Penambahan prebiotik meningkatkan serat pangan dalam kefir yang berperan dalam menekan produksi glukosa (Wahyuni dan Syauqy 2015). Penelitian pada lansia yang mengalami diabetes mellitus tipe 2 menunjukkan penurunan kadar glukosa darah dari $131 \mathrm{mg} \mathrm{mL}^{-1}$ menjadi $120 \mathrm{mg} \mathrm{mL}^{-1}$ setelah pemberian prebiotik $250 \mathrm{~g}$ per hari selama 28 hari (Cressey et al. 2014).

Prebiotik dan probiotik secara sinergis berkombinasi membentuk sinbiotik (Markowiak dan Ślizewska 2017). Kefir tepung pisang batu ( $M$. balbisiana) merupakan sinbiotik yang berperan dalam metabolisme glukosa dan sensitivitas insulin pada hiperglikemia (Markowiak dan Ślizewska 2017). Menurut Verbeke et al. (2015), prebiotik FOS difermentasi menghasilkan short chain fatty acid (SCFA) yang menekan produksi glukosa dan memperbaiki sensitivitas insulin. Pati resisten (Setiarto et al. 2015) dan inulin juga menghasilkan SCFA (Wahyuni dan Syauqy 2015). Pemberian sinbiotik $4 \mathrm{~g}$ per tikus per hari selama delapan minggu menurunkan kadar glukosa darah sebesar $36,8 \%$ pada tikus Sprague Dawley yang diinduksi high fat sucrose diet (Bomhof et al. 2014). Tikus Sprague Dawley dipilih karena lebih sensitif terhadap diet tinggi lemak (Wahyuni dan Syauqy 2015). Oleh karena itu, penelitian ini bertujuan untuk menganalisis pengaruh sinbiotik kefir tepung pisang batu ( $M$. balbisiana) terhadap kadar glukosa darah 
tikus sindrom metabolik yang belum pernah dilakukan sebelumnya.

\section{BAHAN DAN METODE}

\section{Tempat dan waktu penelitian}

Penelitian dilakukan mulai dari Maret sampai dengan Juli 2019 di Laboratorium Fakultas Teknologi Pertanian Universitas Gadjah Mada untuk pembuatan sinbiotik kefir tepung pisang batu ( $M$. balbisiana) dan di Laboratorium Pusat Studi Pangan dan Gizi Universitas Gadjah Mada untuk pengujian preklinis.

\section{Bahan dan alat}

Bahan yang digunakan dalam penelitian ini yaitu: 1) susu skim kambing (Sukamilk dutch goat milk produksi PT Lucas Transmamin Perkasa, Bandung-Indonesia), starter kefir (Yógourmet freeze-dried kefir starter produksi Lyo-San Incorporation, LachuteKanada), dan tepung pisang batu ( $M$. balbisiana) (pembuatan dilakukan di Southeast Asian Food and Agricultural Science and Technology Center, BogorIndonesia) untuk proses pembuatan sinbiotik kefir tepung pisang batu ( $M$. balbisiana) yang didapatkan di kebun yang berlokasi di Kecamatan Limo, Kota Depok, Jawa Barat (S 6 ${ }^{\circ} 22^{\prime} 34.81^{\prime \prime}$, E $106^{\circ} 47^{\prime}$ 19.118"), dan 2) pakan standar (Comfeed AD II produksi PT Japfa Comfeed Indonesia Tbk, Sragen-Indonesia), aquadest, fruktosa murni, kuning telur bebek, minyak babi (Chicharon pork oil, Jakarta-Indonesia), sinbiotik kefir tepung pisang batu ( $M$. balbisiana), ketamine $10 \%$, reagen (phosphate buffer, phenol, 4aminoantipyrine, glucose oxidase (GOD), peroxidase (POD), dan sampel serum darah hewan coba untuk pengujian preklinis.

Alat yang digunakan dalam penelitian ini yaitu: 1) timbangan digital, panci, termometer, sendok, kompor gas, toples kaca, kain penutup, saringan, inkubator, dan lemari pendingin untuk proses pembuatan sinbiotik kefir tepung pisang batu $(M$. balbisiana), dan 2) sendok, gelas ukur, kandang hewan, timbangan, jangka sorong, nipple drinker, syringe $3 \mathrm{cc}$, needle $23 \mathrm{G}$, microtube $2 \mathrm{cc}$, mikro pipet, tabung reaksi, inkubator, sentrifugator, dan fotometer untuk pengujian preklinis.

\section{Metode}

Penelitian ini telah memperoleh persetujuan ethical clearance dari Komisi Etik Penelitian Kesehatan (KEPK) Universitas Pembangunan Nasional "Veteran" Jakarta Nomor B/2078/VII/2019/KEPK. Penelitian ini termasuk dalam penelitian true experimental dengan rancangan pretest posttest with control group menggunakan tikus Sprague Dawley jantan. Inklusi yang digunakan yaitu tikus sehat yang ditandai dengan tikus bergerak aktif, berjenis kelamin jantan, berat badan 150-200 g, dan berusia 8-12 minggu. Tikus tidak diikutsertakan dalam penelitian jika memiliki kriteria eksklusi yaitu tikus mengalami diare selama penelitian, mengalami penurunan berat badan lebih dari $10 \%$, atau mati selama penelitian.

Rancangan ini menggunakan penentuan besar sampel menurut World Health Organization (WHO) yaitu setiap kelompok minimal lima ekor (WHO 2000) dengan penambahan kemungkinan drop out $20 \%$, sehingga didapatkan enam subjek untuk setiap kelompok. Tikus sebanyak 24 ekor dibagi secara acak dengan metode simple random sampling menjadi empat kelompok, yaitu kelompok kontrol negatif $(\mathrm{K}-)$, kelompok kontrol positif $(\mathrm{K}+)$, kelompok perlakuan I $(\mathrm{PI})$, dan kelompok perlakuan II (PII). Kelompok $\mathrm{K}$ - adalah tikus dalam kondisi sehat, sedangkan kelompok $\mathrm{K}+$ adalah tikus kondisi sindrom metabolik. Kelompok PI dan PII adalah tikus kondisi sindrom metabolik yang diberikan sinbiotik kefir tepung pisang batu ( $M$. balbisiana) dengan dosis yang berbeda. Penentuan dosis tersebut berdasarkan pada konversi anjuran dosis pada manusia seberat $70 \mathrm{~kg}$ sebanyak $100 \mathrm{~mL}$ (Rahmawati et al. 2017) dan $200 \mathrm{~mL}$ (Moroti et al. 2012) sehingga didapatkan dosis tikus seberat $200 \mathrm{~g}$ sebanyak 1,8 mL $200 \mathrm{~g}^{-1}$ BB tikus per hari (PI) dan 3,6 mL $200 \mathrm{~g}^{-1} \mathrm{BB}$ tikus per hari (PII).

Pembuatan sinbiotik kefir tepung pisang batu ( $M$. balbisiana) dilakukan sebanyak enam kali selama tiga minggu perlakuan. Produk dibuat melalui beberapa tahap (Gambar 2), yaitu: 1) penimbangan bahan baku berupa susu skim kambing, starter kefir, dan tepung pisang batu ( $M$. balbisiana) menggunakan timbangan digital, 2) pasteurisasi susu skim kambing pada suhu $80^{\circ} \mathrm{C}$ selama 15 menit, 3) pencampuran tepung pisang batu ( $M$. balbisiana) dengan 
susu skim kambing, 4) pendinginan hingga suhu $\left.25^{\circ} \mathrm{C}, 5\right)$ penambahan starter kefir yang telah ditumbuhkan dalam media susu skim kambing, 6) inokulasi dalam inkubator pada suhu $37^{\circ} \mathrm{C}$ selama 24 jam hingga $\mathrm{pH}$ mencapai 4,6, 7) penyaringan starter kefir, dan 8) penyimpanan dalam lemari pendingin pada suhu $4^{\circ} \mathrm{C}$. (Setyawardani et al. 2017, Azara et al. 2018).

Tikus dipelihara dalam kandang berventilasi cukup, pencahayaan cukup, suhu ruang $25^{\circ} \mathrm{C}$, dan dikandangkan secara individual (Gambar 1A). Pakan standar dan aquades diberikan setiap hari secara ad libitum. Pakan standar mengandung air maksimal $12 \%$, protein minimal $15 \%$, lemak 3-7\%, serat maksimal 6\%, abu maksimal 7\%, kalsium $\quad 0,9-1,1 \%$, fosfor $0,6-0,9 \%$, antibiotika (+), dan coccidiostat (+). Pengukuran berat badan menggunakan timbangan dan pengukuran panjang badan
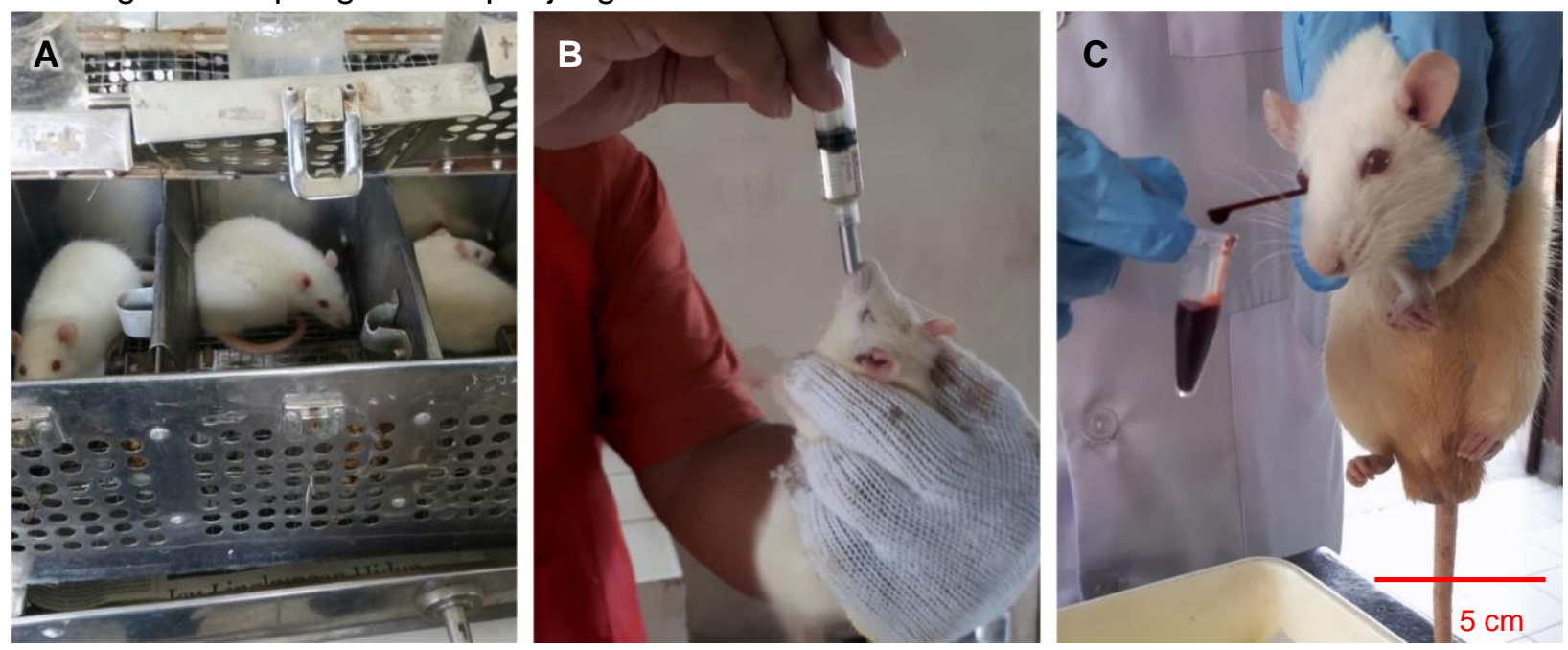

Gambar 1. Hewan coba tikus yang digunakan dalam penelitian: (A) tikus dalam kandang individual, (B) pemberian sinbiotik kefir tepung pisang batu (M. balbisiana), (C) pengambilan sampel darah
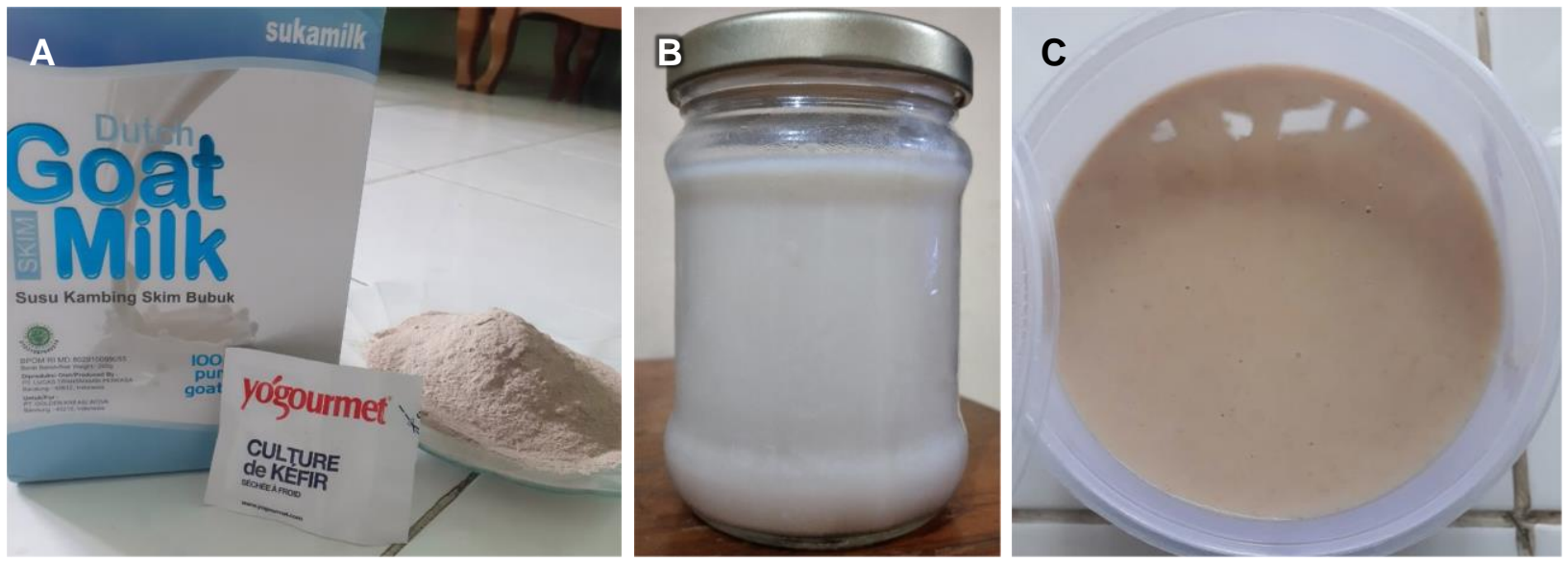

Gambar 2. Sinbiotik kefir tepung pisang batu (M. balbisiana): (A) bahan baku produk, $(B)$ inokulasi produk, (C) hasil penyaringan sinbiotik kefir tepung pisang batu (M. balbisiana) 
dibandingkan dengan tikus sehat pada kelompok K- (Wahyuni dan Syauqy 2015).

Sinbiotik kefir tepung pisang batu ( $M$. balbisiana) diberikan setelah pengondisian sindrom metabolik untuk kelompok PI dan PII. Intervensi produk diberikan selama tiga minggu (Mohamed et al. 2017) pada pagi hari secara oral menggunakan feeding tube (gavage) (Gambar 1B). Pengukuran kadar glukosa darah dilakukan sebelum dan setelah intervensi. Sampel serum darah diambil sebanyak $2 \mathrm{~mL}$ melalui plexus retroorbitalis (Gambar 1C) dan disentrifugasi dengan kecepatan 4.000 rpm selama 10 menit untuk mendapatkan serum darah. Glukosa pada serum darah dianalisis menggunakan metode glucose oxidase-peroxidase aminoantipyrine (GOD-PAP) menggunakan fotometer pada panjang gelombang $546 \mathrm{~nm}$ selama 60 menit (Diasys Diagnostic System 2012).

Analisis univariat digunakan pada penelitian ini untuk melihat mean, median, dan standar deviasi (SD). Analisis bivariat dimulai dengan uji normalitas menggunakan uji Shapiro Wilk $(n \leq 50)$. Analisis dilanjutkan dengan menggunakan uji parametrik paired sample $T$ test jika data berdistribusi normal atau uji nonparametrik Wilcoxon jika data tidak berdistribusi normal untuk menganalisis kadar glukosa darah sebelum dan setelah intervensi.

\section{HASIL DAN PEMBAHASAN}

Hasil uji normalitas menggunakan uji Shapiro Wilk menunjukkan data terdistribusi normal $(p>0,05)$ sehingga digunakan mean atau rerata sebagai ukuran pemusatan dan SD sebagai ukuran penyebaran. Berdasarkan uji homogenity of varian, rerata hasil TG, HDL, dan GDP menunjukkan varian data homogen $(p>0,05)$ dan dilanjutkan dengan uji statistik parametrik one way anova yang menunjukkan perbedaan rerata hasil TG, HDL, dan GDP yang signifikan setiap kelompok $(p=0,000)$. Pengujian dilanjutkan dengan uji Post Hoc Bonferroni untuk mengetahui perbedaan antarkelompok. Hasil uji yang diperoleh dapat dilihat pada Tabel 1.

Berdasarkan Tabel 1, terdapat perbedaan yang signifikan antara kelompok $\mathrm{K}$ - dengan kelompok $\mathrm{K}+$, $\mathrm{PI}$, dan PII. Kelompok K- memiliki TG dan GDP yang lebih rendah serta HDL yang lebih tinggi dibandingkan dengan kelompok lainnya. Tikus kelompok $\mathrm{K}$ - digunakan sebagai gambaran TG, HDL, dan GDP tikus normal (Wahyuni dan Syauqy 2015). Pemberian HFFD selama 2 minggu menyebabkan kelompok $\mathrm{K}+$, $\mathrm{PI}$, dan PII mengalami hipertrigliseridemia (rerata hasil TG 154,75 \pm $2,81 \mathrm{mg} \mathrm{dL}^{-1}$ ), penurunan HDL (rerata hasil HDL 25,11 $\pm 1,72 \mathrm{mg} \mathrm{dL}^{-1}$ ) dan hiperglikemia (rerata hasil GDP 131,39 $\pm 2,01 \mathrm{mg} \mathrm{dL}^{-1}$ ) dibandingkan dengan kelompok $\mathrm{K}-$ (Tabel 2). Rerata hasil TG, HDL, dan GDP kelompok $\mathrm{K}+$, PI, dan PII tidak sesuai dengan nilai normal sehingga didapatkan kondisi sindrom metabolik.

Berdasarkan hasil uji normalitas menggunakan uji Shapiro Wilk menunjukkan data terdistribusi normal $(p>0,05)$ sehingga dilanjutkan uji statistik parametrik paired sample $T$ test untuk mengetahui perbedaan rerata hasil GDP sebelum dan setelah intervensi. Hasil uji yang diperoleh dapat dilihat pada Tabel 3.

Tabel 3 menunjukkan perbedaan rerata hasil GDP sebelum dan setelah intervensi serta perubahan rerata hasil GDP sebelum dan setelah intervensi. Kelompok $\mathrm{K}-(\mathrm{p}=0,008)$ dan $\mathrm{K}+(\mathrm{p}=0,000)$ mengalami peningkatan GDP yang signifikan ( $p \leq 0,05)$, sedangkan kelompok PI $(p=0,000)$ dan PII $(p=0,000)$ mengalami penurunan GDP yang signifikan $(p \leq 0,05)$. Penurunan GDP pada kelompok PI yaitu sebesar $22 \%$ dan sebesar $36 \%$ pada kelompok PII.

Pengondisian sindrom metabolik pada subjek didapat melalui pemberian HFFD selama dua minggu. Kondisi sindrom metabolik diketahui dengan membandingkan rerata hasil pemeriksaan TG, HDL, dan GDP antara kelompok $\mathrm{K}+, \mathrm{PI}$, dan PII dengan kelompok K-. Pemberian HFFD dilakukan karena asupan fruktosa berlebih menyebabkan hiperglikemia akibat kegagalan sinyal insulin yang menurunkan sintesis glikogen dan meningkatkan glukoneogenesis (Rahmawati et al. 2017). Asupan fruktosa berlebih akan diubah menjadi asam lemak bebas, asam laktat, dan asam urat yang berpengaruh terhadap resistensi insulin (Zhang et al. 2017). Produksi asam lemak bebas akan menstimulasi aktivitas lipogenesis sehingga menyebabkan hipertrigliseridemia (AlvesBezerra dan Cohen 2018). 
Tabel 1. Rerata hasil TG, HDL, dan GDP subjek setiap kelompok

\begin{tabular}{lcccc}
\hline \multirow{2}{*}{ Kelompok } & $\mathrm{n}$ & \multicolumn{3}{c}{ Rerata hasil $\pm \mathrm{SD}$} \\
\cline { 3 - 4 } & & $\mathrm{TG}\left(\mathrm{mg} \mathrm{dL}^{-1}\right)$ & $\mathrm{HDL}\left(\mathrm{mg} \mathrm{dL}^{-1}\right)$ & $\mathrm{GDP}\left(\mathrm{mg} \mathrm{dL}^{-1}\right)$ \\
\hline K- & 6 & $67,60 \pm 3,92^{\mathrm{a}}$ & $78,66 \pm 2,22^{\mathrm{a}}$ & $71,02 \pm 1,799^{\mathrm{a}}$ \\
$\mathrm{K}+$ & 6 & $154,08 \pm 2,66^{\mathrm{b}^{\star}}$ & $25,84 \pm 1,7 \mathrm{~b}^{\star}$ & $132,29 \pm 1,43^{\mathrm{b}^{*}}$ \\
PI & 6 & $154,35 \pm 3,02^{\mathrm{b}^{\star}}$ & $24,45 \pm 1,13^{\mathrm{b}^{\star}}$ & $130,44 \pm 1,99 \mathrm{~b}^{\star}$ \\
PII & 6 & $155,82 \pm 2,92^{\mathrm{b}^{*}}$ & $25,03 \pm 2,12^{\mathrm{b}^{*}}$ & $131,45 \pm 2,37 \mathrm{~b}^{\star}$ \\
$p$ & & $0,000^{1}$ & $0,000^{1}$ & $0,000^{1}$ \\
\hline
\end{tabular}

Keterangan: *Kondisi Sindrom Metabolik; ${ }^{1}$ Signifikansi hasil uji one way anova; a bNotasi berbeda menunjukkan perbedaan signifikan pada uji Post Hoc Bonferroni

Tabel 2. Rerata hasil pengondisian Sindrom Metabolik subjek

\begin{tabular}{lcc}
\hline Variabel & Nilai Normal \pm SD & Rerata Hasil \pm SD \\
\hline TG $\left(\mathrm{mg} \mathrm{dL}^{-1}\right)$ & $67,60 \pm 3,92$ & $154,75 \pm 2,81$ \\
$\mathrm{HDL}\left(\mathrm{mg} \mathrm{dL}^{-1}\right)$ & $78,66 \pm 2,22$ & $25,11 \pm 1,72$ \\
$\mathrm{GDP}\left(\mathrm{mg} \mathrm{dL}^{-1}\right)$ & $71,02 \pm 1,79$ & $131,39 \pm 2,01$ \\
\hline
\end{tabular}

Tabel 3. Rerata hasil GDP (mg dL $\left.{ }^{-1}\right)$ sebelum dan setelah intervensi

\begin{tabular}{|c|c|c|c|c|c|c|}
\hline \multirow{2}{*}{ Kelompok } & \multirow{2}{*}{$\mathrm{n}$} & \multicolumn{2}{|c|}{ Rerata \pm SD } & \multirow{2}{*}{$P$} & \multicolumn{2}{|c|}{$\Delta$ Perubahan } \\
\hline & & Sebelum & Setelah & & Rerata \pm SD & $\%$ \\
\hline $\mathrm{K}-$ & 6 & $71,02 \pm 1,79$ & $72,84 \pm 1,76$ & $0,008^{1}$ & $1,83 \pm 1,05$ & $2,6 \%$ \\
\hline $\mathrm{K}+$ & 6 & $132,29 \pm 1,43$ & $133,45 \pm 1,43$ & $0,000^{1}$ & $1,17 \pm 0,24$ & $1 \%$ \\
\hline $\mathrm{PI}$ & 6 & $130,44 \pm 1,99$ & $102,06 \pm 2,15$ & $0,000^{1}$ & $-28,38 \pm 3,59$ & $-22 \%$ \\
\hline PII & 6 & $131,45 \pm 2,37$ & $83,81 \pm 3,72$ & $0,000^{1}$ & $-47,64 \pm 4,30$ & $-36 \%$ \\
\hline
\end{tabular}

Keterangan: ${ }^{1}$ Signifikansi hasil uji Paired Sample T Test

Asupan lemak berlebih menurunkan ekspresi glucose transporter-4 (GLUT-4) sehingga transportasi glukosa ke dalam membran sel terganggu yang menyebabkan hiperglikemia (Rahmawati et al. 2017). Selain itu, asupan lemak berlebih pada jaringan adiposa meningkatkan aktivitas lipogenesis dan meningkatkan produksi asam lemak bebas sehingga terjadi mobilisasi asam lemak bebas yang berikatan dengan gliserol membentuk TG (Octavia et al. 2017). Asupan lemak berlebih juga meningkatkan lowdensity lipoprotein (LDL) dan kolesterol yang memicu pemecahan HDL densitas rendah oleh lipase kinetik sehingga terjadi penurunan HDL (Jung dan Choi 2014). Pemberian HFFD pada kelompok $\mathrm{K}+$, PI, dan PII juga menyebabkan subjek mengalami obesitas (Indeks Lee >300) (Zein et al. 2017). Hal tersebut terlihat pada rerata Indeks Lee kelompok K+, PI, dan PII yaitu 319,34 dibandingkan dengan kelompok $\mathrm{K}$ - yaitu 284,89 . Peningkatan aktivitas lipogenesis yang menyebabkan obesitas membuat kondisi toleransi glukosa terganggu sehingga sel $\beta$ pankreas tidak dapat mengimbangi peningkatan kebutuhan insulin yang akan memicu terjadinya hiperglikemia, penurunan HDL, dan hipertrigliseridemia (ADA 2018).

Kadar glukosa darah setelah intervensi pada kelompok $\mathrm{K}-$ dan $\mathrm{K}+$ mengalami peningkatan sebesar masing-masing 2,6\% dan $1 \%$. Peningkatan GDP pada kelompok $\mathrm{K}$ - disebabkan oleh usia tikus yang memasuki usia dewasa awal (Nurmawati 2017) yaitu usia 14 minggu pada akhir intervensi. Secara fisiologis, penambahan usia menyebabkan penurunan fungsi dari sel $\beta$ pankreas (Setiyorini dan Wulandari 2017). Sel $\beta$ pankreas akan melemah hingga mengalami kerusakan yang memicu terjadinya hiperglikemia (Rahmawati et al. 2017). Peningkatan GDP pada kelompok K+ kemungkinan disebabkan oleh pemberian HFFD selama dua minggu tanpa pemberian sinbiotik kefir tepung pisang batu $(M$. 
balbisiana). Kadar glukosa darah setelah intervensi pada kelompok PI dan PII mengalami penurunan sebesar $22 \%$ dan $36 \%$. Hasil penelitian ini didukung oleh penelitian Asgharzadeh et al. (2017) yang menunjukkan pemberian sinbiotik $2 \mathrm{~mL}$ per tikus per hari selama 30 hari dapat menurunkan kadar glukosa darah sebesar $11 \%$ melalui mekanisme perbaikan sel $\beta$ pankreas.

Pemberian sinbiotik kefir tepung pisang batu ( $M$. balbisiana) lebih besar dalam menurunkan GDP dibandingkan dengan penelitian sebelumnya. Penurunan GDP disebabkan oleh pakan standar yang mengandung serat pangan (Wahyuni dan Syauqy 2015) yaitu sebesar 6\%. Serat pangan berperan dalam memodulasi fungsi fisiologis tubuh berupa efek hipoglikemia (Moroti et al. 2012). Serat pangan dapat menghambat penyerapan glukosa dalam saluran pencernaan (Sardá et al. 2018). Serat pangan pada pakan standar yang dikonsumsi setiap hari membantu menurunkan GDP (Wahyuni dan Syauqy 2015), tetapi perbedaan penurunan GDP yang signifikan pada kelompok PI dan PII terjadi karena dosis perlakuan yang berbeda.

Keberadaan tepung pisang batu ( $M$. balbisiana) sebagai prebiotik akan memengaruhi pertumbuhan probiotik dalam kefir susu kambing. Prebiotik merupakan serat pangan terfermentasi yang memberikan perubahan spesifik pada komposisi atau aktivitas mikroflora usus (Markowiak dan Ślizewska 2017). Prebiotik dalam pisang batu (M. balbisiana) dapat berupa FOS, pati resisten (Setiarto et al. 2015), dan inulin (Wahyuni dan Syauqy 2015). Prebiotik dapat menghambat penyerapan glukosa dalam saluran pencernaan dengan cara menurunkan waktu transit makanan (Wahyuni dan Syauqy 2015) dan menghambat pengosongan lambung (Rahmawati et al. 2017). Prebiotik akan memengaruhi pertumbuhan probiotik dengan menyediakan substrat spesifik untuk proses fermentasi (Moroti et al. 2012). Probiotik dalam kefir susu kambing dibuat dengan penambahan bakteri asam laktat (BAL) yaitu Lactobacillus lactis, $L$. cremoris, $L$. diacetylactis, dan L. acidophilus (Azara et al. 2018) serta khamir Saccharomyces cerevisiae yang berkontribusi untuk menyediakan faktor pertumbuhan bakteri probiotik (Li et al. 2011). Probiotik memainkan peran saat hiperglikemia dalam metabolisme glukosa dan sensitivitas insulin sehingga kadar glukosa darah dapat terkontrol (Markowiak dan Ślizewska 2017). Probiotik akan memodulasi sistem imunitas dan memelihara mikroflora usus sehingga terjadi penurunan resistensi insulin (Rahmawati et al. 2017).

Kombinasi probiotik dan prebiotik menjadi sinbiotik berperan dalam metabolisme glukosa pada hiperglikemia (Markowiak dan Ślizewska 2017). Prebiotik akan difermentasi oleh BAL untuk menghasilkan SCFA (Verbeke et al. 2015), khususnya asam propionat yang dapat menghambat glukoneogenesis dan meningkatkan glikolisis (Wahyuni dan Syauqy 2015). Peningkatan SCFA pada mikroflora usus akan meningkatkan ekspresi dari GLUT-4 untuk meningkatkan sensitivitas insulin (Yan dan Ajuwon 2015) dan peningkatan kadar glukosa darah ke dalam membran sel (Rahmawati et al. 2017) sehingga terjadi penurunan kadar glukosa darah (Olson 2012). Peningkatan dari jumlah SCFA tersebut dipengaruhi oleh jumlah BAL dalam sinbiotik kefir tepung pisang batu $(M$. balbisiana) yang meningkat (Wahyuni dan Syauqy 2015).

Berdasarkan penelitian pendahuluan tentang formulasi kefir susu kambing dengan penambahan $4 \%$ tepung pisang batu $(M$. balbisiana), menunjukkan kadar air $85,47 \%$, kadar lemak $0,24 \%$, kadar protein $4,44 \%$, kadar karbohidrat $8,56 \%$, kadar serat kasar

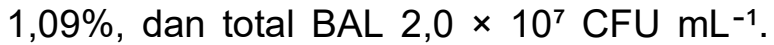
Penelitian tersebut berbeda dengan penelitian Prastiwi et al. (2018) tanpa penambahan prebiotik yang menunjukkan total BAL hanya $9,80 \times 10^{6} \mathrm{CFU} \mathrm{mL}^{-1}$. Hal tersebut menunjukkan penambahan prebiotik dapat meningkatkan total BAL yang berpengaruh terhadap metabolisme glukosa dalam tubuh (Wahyuni dan Syauqy 2015). Perbedaan penurunan kadar glukosa darah sebanyak $28,38 \pm 3,59 \mathrm{mg} \mathrm{dL}^{-1}(22 \%)$ pada $\mathrm{PI}$ dan $47,64 \pm 4,30 \mathrm{mg} \mathrm{dL}^{-1}(36 \%)$ pada PII terjadi karena pemberian dosis sinbiotik kefir tepung pisang batu (M. balbisiana) yang lebih banyak pada kelompok PII. Perbedaan dosis tersebut memengaruhi peningkatan jumlah BAL dalam saluran pencernaan sehingga terjadi penurunan kadar glukosa darah yang lebih besar pada kelompok PII. 


\section{KESIMPULAN}

Berdasarkan hasil penelitian dapat disimpulkan bahwa pemberian sinbiotik kefir tepung pisang batu ( $M$. balbisiana) dapat menurunkan kadar glukosa darah tikus sindrom metabolik sebanyak $28,38 \pm 3,59 \mathrm{mg}$ $\mathrm{dL}^{-1}(22 \%)$ pada kelompok $\mathrm{PI}$ dan sebanyak 47,64 $\pm 4,30 \mathrm{mg} \mathrm{dL}^{-1}$ (36\%) pada kelompok PII. Penurunan kadar glukosa darah disebabkan oleh peningkatan jumlah BAL dalam saluran pencernaan yang memengaruhi jumlah SCFA sehingga berpengaruh terhadap metabolisme glukosa dalam tubuh. Saran untuk penelitian selanjutnya perlu dilakukan pengukuran jumlah BAL dalam saluran pencernaan hewan coba sehingga dapat membuktikan penurunan glukosa darah terjadi karena peningkatan produksi SCFA.

\section{UCAPAN TERIMA KASIH}

Penulis menyampaikan terima kasih kepada Lembaga Penelitian dan Pengabdian kepada Masyarakat (LPPM) Universitas Pembangunan Nasional "Veteran" Jakarta yang telah memberikan hibah dana serta seluruh pihak yang telah membantu terbentuknya karya tulis ini.

\section{DAFTAR PUSTAKA}

ADA (2018) 2. Classification and diagnosis of diabetes: Standards of medical care in diabetes-2018. American Diabetes Association. Diabetes Care 41:S13-S7. doi: 10.2337/dc18-S002

Al-Shemmari IGM, Altaee RAK, Hassan AH (2018) Evaluation of antidiabetic and antihyperlipidimic activity of kefir in alloxan induced diabetes mellitus rats. Sci J Med Res 2:83-86. doi: 10.37623/SJMR.2018.2606

Alves-Bezerra M, Cohen DE (2018) Triglyceride metabolism in the liver. Compr Physiol 8:1-22. doi: 10.1002/cphy.c170012

Asgharzadeh F, Tanomand A, Ashoori MR, Asgharzadeh A, Zarghami N (2017) Investigating the effects of Lactobacillus casei on some biochemical parameters in diabetic mice. J Endocrinol Metab Diabetes South Africa 22:47-50. doi: $10.1080 / 16089677.2017 .1378460$
Azara R, Saidi IA, Giyanto (2018) Yeast and lactic acid bacteria on kefir instant filled with flour of banana (Musa paradisiaca cultivar Mas). IOP Conf Ser Mater Sci Eng 420:1-5. doi: 10.1088/1757899X/420/1/012068

Bomhof MR, Saha DC, Reid DT, Paul HA, Reimer RA (2014) Combined effects of oligofructose and Bifidobacterium animalis on gut microbiota and glycemia in obese rats. Obesity 22:763-771. doi: 10.1002/oby.20632

Cressey R, Kumsaiyai W, Mangklabruks A (2014) Daily consumption of banana marginally improves blood glucose and lipid profile in hypercholesterolemic subjects and increases serum adiponectin in type 2 diabetic patients. Indian J Exp Biol 52:1173-1181

Damiri B, Alhala AA, Najjar L, Alqadome S (2018) Metabolic syndrome and its risk factors among overweight and obese Palestinian schoolchildren using IDF and NCEP-ATP/III definitions. Ann Clin Lab Res 6:1-8. doi: 10.21767/23865180.100242

Diasys Diagnostic System (2012) Glucose GOD FS - Diagnostic reagent for quatitative in vitro determination of glucose in serum or plasma on photometric systems. DiaSys Diagnostic System, Jerman

Fernandes J, Lofgren IE (2011) Prevalence of metabolic syndrome and individual criteria in college students. J Am Coll Health 59:313-321. doi: $10.1080 / 07448481.2010 .508084$

Gandhi K (2017) Approach to hypoglycemia in infants and children. Transl Pediatr 6:408-420. doi: $10.21037 /$ tp.2017.10.05

Gill RM, Khan SA, Jackson RT, Duane M (2017) Prevalence of the metabolic syndrome in Central and South American immigrant residents of the Washington DC area. J Nutr Metab 2017:9531964. doi: $10.1155 / 2017 / 9531964$

Govers E (2015) Obesity and insulin resistance are the central issues in prevention of and care for comorbidities. Healthcare 3:408-416. doi: 10.3390/healthcare3020408

Jung UJ, Choi MS (2014) Obesity and its metabolic complications: The role of adipokines and the relationship 
between obesity, inflammation, insulin resistance, dyslipidemia and nonalcoholic fatty liver disease. Int $\mathrm{J}$ Mol Sci 15:6184-6223. doi: 10.3390/ijms15046184

Li M, Liao X, Zhang D, Du G, Chen J (2011) Yeast extract promotes cell growth and induces production of polyvinyl alcoholdegrading enzymes. Enzyme Res 2011:179819. doi: 10.4061/2011/179819

Markowiak P, Ślizewska K (2017) Effects of probiotics, prebiotics, and synbiotics on human health. Nutrients 9:E1021. doi: 10.3390/nu9091021

Martharini D, Indratiningsih I (2017) Kualitas mikrobiologis dan kimiawi kefir susu kambing dengan penambahan Lactobacillus acidophilus FNCC 0051 dan tepung kulit pisang kepok (Musa paradisiaca). Agritech 37:22-29. doi: 10.22146/agritech.17002

Martínez-Castaño M, Lopera-Idarraga J, Pazmiño-Arteaga J, Gallardo-Cabrera C (2019) Evaluation of the behaviour of unripe banana flour with non-conventional flours in the production of gluten-free bread. Food Sci Technol Int 26:160-172. doi: 10.1177/1082013219873246

Mohamed DA, Hassanein MM, El-Messery TM, Fouad MT, El-Said MM, Fouda KA, Abdel-Raze AG (2017) Amelioration of diabetes in a rat model through yoghurt supplemented with probiotics and olive pomace extract. J Biol Sci 17:320-333. doi: 10.3923/jbs.2017.320.333

Moroti C, Magri LFS, Costa MR, Cavallini DCU, Sivieri K (2012) Effect of the consumption of a new symbiotic shake on glycemia and cholesterol levels in elderly people with type 2 diabetes mellitus. Lipids Health Dis 11:29. doi: 10.1186/1476-511X-11-29

Muhidin, Sadimantara GR, Leomo S, Yusuf DN, Rakian TC (2019) Characterizing the vegetative and fruit of local dwarf banana cavendish from SE Sulawesi. IOP Conf Ser Earth Environ Sci 260:1-5. doi: 10.1088/1755-1315/260/1/012175

Musita N (2012) Kajian karakteristik gula cair fruktooligosakarida dari pisang batu. Prosiding SN-SMAIP III 28-29 Juni 2012. FMIPA UNILA, Bandar Lampung, hal 464-469

Nurliyani, Harmayani E, Sunarti (2015) Antidiabetic potential of kefir combination from goat milk and soy milk in rats induced with streptozotocinnicotinamide. Korean J Food Sci Anim Resour 35:847-858. doi: 10.5851/kosfa.2015.35.6.847

Nurmawati T (2017) Studi respon fisiologis dan kadar gula darah pada tikus putih (Rattus norvegicus) yang terpapar streptozotocin (STZ). J Ners dan Kebidanan 4:244-247. doi: 10.26699/jnk.v4i3.art.p244-247

Octavia ZF, Djamiatun K, Suci N (2017) Pengaruh pemberian yogurt sinbiotik tepung pisang tanduk terhadap profil lipid tikus sindrom metabolik. J Gizi Klin Indones 13:159-169. doi: 10.22146/ijcn.19369

Olson AL (2012) Regulation of GLUT4 and insulin-dependent glucose flux. ISRN Mol Biol 2012:856987. doi: 10.5402/2012/856987

Prastiwi VF, Bintoro VP, Rizqiati H (2018) Sifat mikrobiologi, nilai viskositas, dan organoleptik kefir optima dengan penambahan high fructose syrup (HFS). J Teknol Pangan 2:27-32. doi: 10.14710/jtp.2.1.\%p

Rahmawati FC, Djamiatun K, Suci N (2017) Pengaruh yogurt sinbiotik pisang terhadap kadar glukosa dan insulin tikus sindrom metabolik. J Gizi Klin Indones 14:10-18. doi: 10.22146/ijcn.19379

Rashid M, Sultana M (2016) Role of probiotics in human and animal health review. J Prob Health 4:148. doi: 10.4172/23298901.1000148

Ruan Y, Sun J, He J, Chen F, Chen R, Chen $H$ (2015) Effect of probiotics on glycemic control: A systematic review and metaanalysis of randomized, controlled trials. PLoS One 10:e0132121. doi: 10.1371/journal.pone.0132121

Sardá FAH, Giuntini EB, Nazare JA, König D, Bahia LR, Lajolo FM, de Menezes EW (2018) Effectiveness of carbohydrates as a functional ingredient in glycemic control. Food Sci Technol 38:561-576. doi: $10.1590 /$ fst.42517

Setiarto RHB, Jenie BSL, Faridah DN, Saskiawan I (2015) Kajian peningkatan pati resisten yang terkandung dalam bahan pangan sebagai sumber prebiotik. J Ilmu Pertan Indones 20:191200. doi: 10.18343/jipi.20.3.191 
Setiyorini E, Wulandari NA (2017) Hubungan status nutrisi dengan kualitas hidup pada lansia penderita diabetes mellitus tipe 2 yang berobat di poli penyakit dalam RSD Mardi Waluyo Blitar. J Ners Kebidanan 4:125-133. doi: 10.26699/jnk.v4i2.ART.P125-133

Setyawardani T, Sumarmono J, Rahardjo AHD, Sulistyowati M, Widayaka K (2017) Kualitas kimia, fisik dan sensori kefir susu kambing yang disimpan pada suhu dan lama penyimpanan berbeda. Bul Peternak 41:298-306. doi: 10.21059/buletinpeternak.v41i3.18266

Srikanthan K, Feyh A, Visweshwar H, Shapiro JI, Sodhi K (2016) Systematic review of metabolic syndrome biomarkers: A panel for early detection, management, and risk stratification in the West Virginian population. Int $\mathrm{J}$ Med Sci 13:25-38. doi: 10.7150/ijms. 13800

Suhaema, Masthalina H (2015) Pola konsumsi dengan terjadinya sindrom metabolik di indonesia. J Kesehatan Masy Nas 9:340-347. doi: 10.21109/kesmas.v9i4.741

Verbeke KA, Boobis AR, Chiodini A, Edwards $C A$, Franck A, Kleerebezem M, Nauta A, Raes J, van Tol EA, Tuohy KM (2015) Towards microbial fermentation metabolites as markers for health benefits of prebiotics. Nutr Res Rev 28:42-66.

doi: 10.1017/S0954422415000037

Wahyuni PT, Syauqy A (2015) Pengaruh pemberian pisang kepok (Musa paradisiaca forma typical) terhadap kadar glukosa darah puasa pada tikus sprague dawley pra sindrom metabolik. $J$ Nutr College 4:547-556. doi: 10.14710/jnc.v4i4.10161

WHO (2000) General guideline for methodologies on research and evaluation of traditional medicine. WHO/EDM/TRM/2000.1. World Health Organization, Geneva

Yan H, Ajuwon KM (2015) Mechanism of butyrate stimulation of triglyceride storage and adipokine expression during adipogenic differentiation of porcine stromovascular cells. PLoS One 10:e0145940. doi: 10.1371/journal.pone.0145940

Yin Q, Chen X, Li L, Zhou R, Huang J, Yang D (2013) Apolipoprotein $B$ /apolipoprotein $A 1$ ratio is a good predictive marker of metabolic syndrome and pre-metabolic syndrome in Chinese adolescent women with polycystic ovary syndrome. J Obstet Gynaecol Res 39:203-209. doi: 10.1111/j.1447-0756.2012.01907.x

Zein EM, Lubis VMT, Purba A (2017) Efek interval training terhadap indeks Lee, kadar adiponektin, dan IL-6 pada tikus model obesitas. MKB 49:15-21. doi: 10.15395/mkb.v49n1.983

Zhang DM, Jiao RQ, Kong LD (2017) High dietary fructose: Direct or indirect dangerous factors disturbing tissue and organ functions. Nutrients 9:E335. doi: $10.3390 /$ nu9040335 